\title{
The Aptian evaporites of the South Atlantic: a climatic paradox?
}

\author{
A.-C. Chaboureau ${ }^{1,2,3}$, Y. Donnadieu ${ }^{2}$, P. Sepulchre ${ }^{2}$, C. Robin ${ }^{1}$, F. Guillocheau ${ }^{1}$, and S. Rohais ${ }^{3}$ \\ ${ }^{1}$ Géosciences Rennes - UMR6118, Université de Rennes 1, Campus de Beaulieu, 263 av. du Général Leclerc, \\ Rennes 35042 Cedex, France \\ ${ }^{2}$ Laboratoire des Sciences du Climat et de l'Environnement, CNRS-CEA, CEA Saclay, Orme des Merisiers, Bat. 701, \\ 91191 Gif-sur-Yvette Cedex, France \\ ${ }^{3}$ IFP Energies nouvelles, 1 et 4 Avenue de Bois-Préau, 92852 Rueil-Malmaison, France
}

Correspondence to: A.-C. Chaboureau (anne-claire.chaboureau@univ-rennes1.fr)

Received: 2 December 2011 - Published in Clim. Past Discuss.: 5 January 2012

Revised: 27 April 2012 - Accepted: 3 May 2012 - Published: 11 June 2012

\begin{abstract}
For a long time, evaporitic sequences have been interpreted as indicative of an arid climate. Such systematic interpretations led to the suggestion that the Central segment of the South Atlantic $\left(20-0^{\circ}\right)$ was characterized by an arid climate during the upper Aptian. Indeed, synchronous to this period that corresponds to the rifting and to the opening of this part of the South Atlantic, a large evaporitic sequence spreads out from the equator to $20^{\circ} \mathrm{S}$. Using the fully ocean atmosphere coupled model FOAM, we test the potential for the Aptian geography to produce an arid area over the Central segment. Sensitivity to the altitude of the rift shoulders separating the Africa and the South America cratons, to the water depth of the Central segment and to the drainage pattern have been performed. Using seawater salinity as a diagnostic, our simulations show that the southern part of the Central segment is characterized by very high salinity in the case of catchment areas draining the water out of the Central segment. Conversely, whatever the boundary conditions used, the northern part of the Central segment remains humid and salinities are very low. Hence, we conclude that the evaporites deposited in the southern part of the Central segment may have been controlled by the climate favouring aridity and high saline waters. In contrast, the evaporites of the northern part can hardly be reconciled with the climatic conditions occurring there and may be due to hydrothermal sources. Our interpretations are in agreement with the gradient found in the mineralogical compositions of the evaporites from the North to the South, i.e. the northern evaporites are at least 4 times more concentrated than the southern one.
\end{abstract}

\section{Introduction}

Several aspects of the Early Cretaceous (anoxic events, associated biological crises, high volcanic activity) make it a very well-studied period, representing a pivotal transition in the global climate system. Despite some short periods of cooling in the Lower Cretaceous (Frakes and Francis, 1988; De Lurio and Frakes, 1999; Price, 1999), this period is characterized by warm polar and tropical temperatures (Frakes, 1999; Puceat et al., 2007), and marked by a gradual warming from Aptian-Albian age to Cenomanian age (Clarke and Jenkyns, 1999; Huber et al., 1995; Puceat et al., 2003).

The Aptian-Albian boundary, 112 million years ago (hereafter Ma), turns out to be a key-period of the Cretaceous with major shift in the paleogeography with the breakup of the Gondwana supercontinent leading to the separation of the South America and Africa (Nürnberg and Müller, 1991; Austin and Uchupi, 1982; Rabinowitz and LaBrecque, 1979). During the latest stage of the breakup at the upper Aptian, a massive evaporitic sequence, from 1 to $2 \mathrm{~km}$ thick, was deposited along the brazilian and african margins (Fig. 1a and b) (Asmus and Ponte, 1973; Brognon and Verrier, 1966; Butler, 1970; Mohriak et al., 2008; Mohriak and Rosendahl, 2003 ) in 1 to 5 millions of years (Davison, 1999; Doyle et al., 1977, 1982; Mussard, 1996; Teisserenc and Villemin, 1990). These evaporites are located in the entire Central segment between the Walvis-Rio Grande Fracture Zone and the Ascension Fracture Zone (Fig. 1). At that time the equatorial segment, further North, also recorded locally evaporite deposition (Fig. 1a). According to recent plate kinematic models, these segments were localized near the equator at that time, 


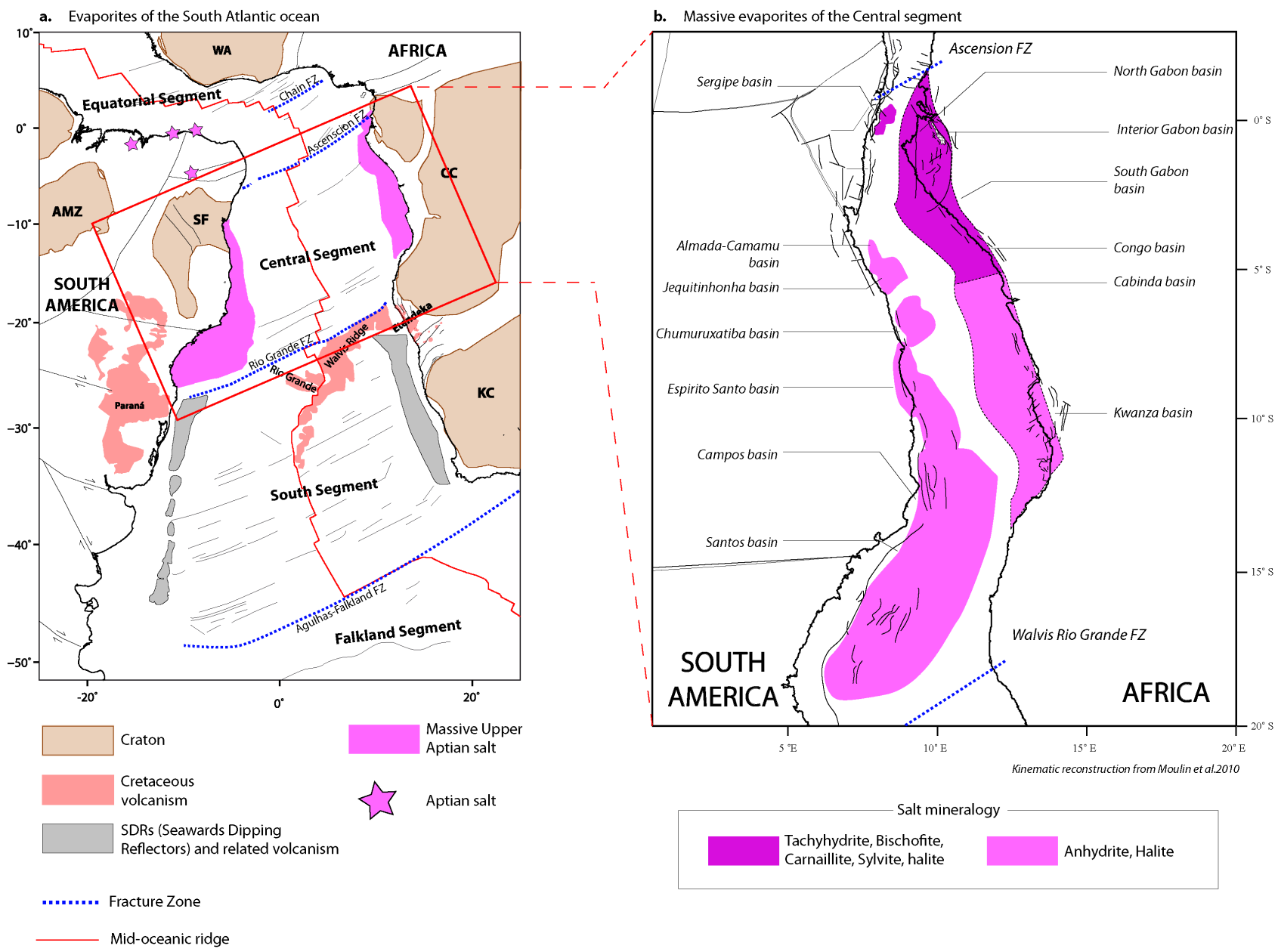

Fig. 1. (a) Location of the Central segment and the salt sequence along the Brazilian and African margin (modified from Moulin et al., 2010). WA, West Africa Craton; CC, Congo Craton; KC, Kalahari Craton; AMZ, Amazonia Craton; SF, São Francisco Craton; FZ, Fracture Zone. (b) Mineralogy of the massive evaporites in the Central segment, at time of filing, according to the cinematic reconstruction of Moulin et al. (2010).

between 0 and $20^{\circ} \mathrm{S}$ for the Central segment, where massive evaporites were deposited (Moulin et al., 2010; Torsvik et al., 2009). Actually, modern evaporites are deposited in semi arid to hyper arid desert, around $20-30^{\circ} \mathrm{N}$ and $\mathrm{S}$ of the Equator (Warren, 2006). These evaporites in the Central and Equatorial segments close to the equator raises many questions about the occurrence and the position of humid climatic belt at this time.

In addition to the massive nature of the evaporites of the Central segment, another feature is their mineralogical composition (Fig. 1b). They contain (1) a small proportion of calcium sulfate compared to the abundance of chloride minerals (sylvite, carnaillite and bischofite), and (2) an unusual calcium chloride salt, the tachyhydrite, in large thicknesses (Belmonte et al., 1965; de Ruiter, 1979; Meister and Aurich, 1971; Teisserenc and Villemin, 1990; Wardlaw, 1972), which precipitates in highly saline brines in excess of $370 \mathrm{psu}$. Although these peculiar evaporites constitute a large proportion of the total salt deposited, they are essentially localized in the Northern part of the Central segment, in the basins of Sergipe, Alagoas, Gabon, and Congo, near the equator according to the palaeogeographic recontructions (Moulin et al., 2010), (Fig. 1b). Further south, evaporites mainly consist of gypsum and halite, which precipitate in the lower salinity brines, respectively, between 150 and 300 , and 300 and $370 \mathrm{psu}$ (Holser, 1979). To explain the presence of the unusual evaporites to the North, Hardie (1990) suggested a hydrothermal water-rock interaction, probable in continental extensional basins, tectonically and magmatically active. This hypothesis raises the question of the role of geodynamic in the development of these evaporites.

Finally, although evaporites are essentially dependent on the climatic conditions, which determines the evaporation rates of sea water and the concentration of the solutions, they also depend on the isolation of the basin. The latter is controlled by the influx of waters with lower salinity, supplied by 


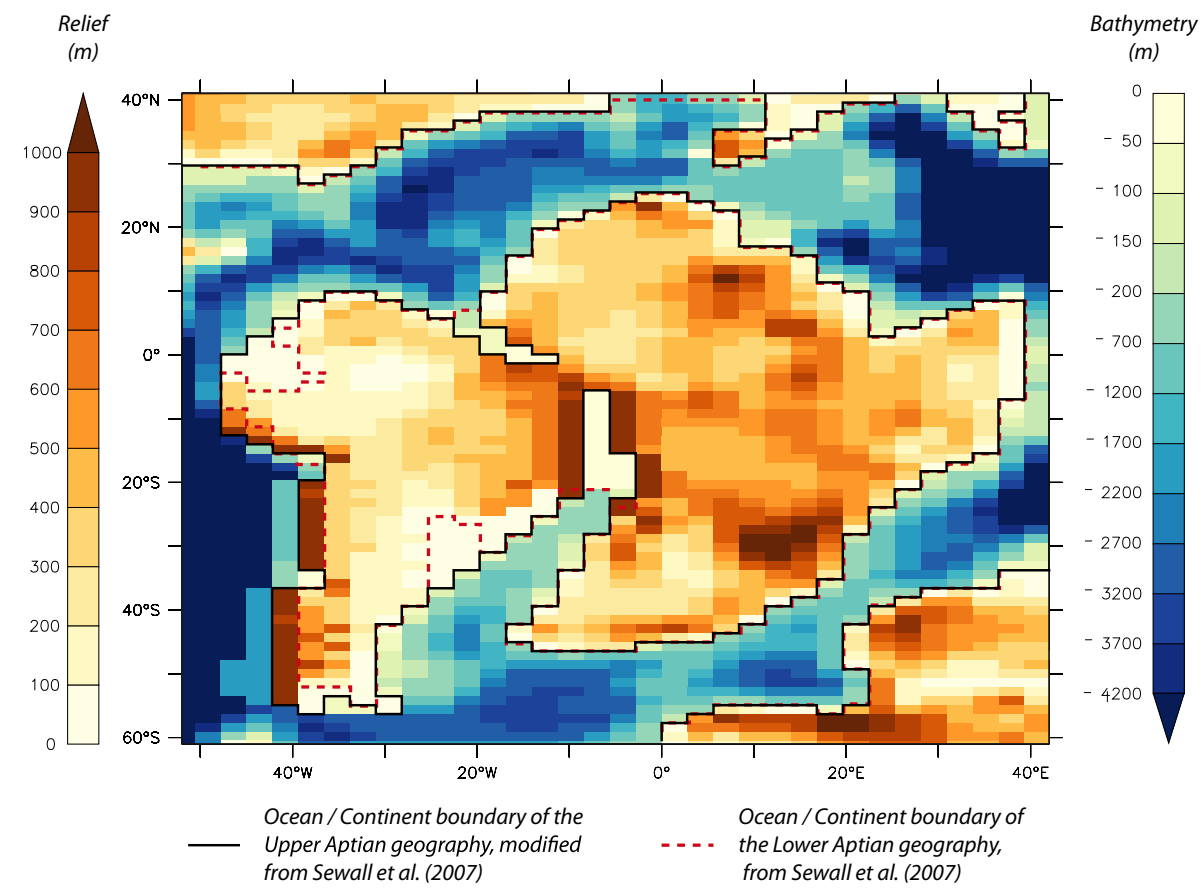

Fig. 2. Topography and bathymetry used in the GCM Model, from Sewall et al. (2007).

seawater or by a fluvial tributary and by the connection with an ocean or a sea, which supplies water of reduced salinity. When the total volume of seawater and freshwater input is lower than the water loss (evaporation), the water evolves to hypersalinity, and allows the deposition of different evaporitic minerals. We can finally ask the question of the influence of paleogeography on the deposition of the South Atlantic evaporites.

Given the location of evaporites, their high mineralogical variability, and the geodynamic specific context during their deposit, crucial issues need to be assessed: What was the climate during the salt deposit and what was the role of the paleogeography? How did these factors control the evaporitic sedimentation in the Central segment, and the repartition of the different evaporites mineralogies? To investigate these questions, we simulate the salinity of the Central Segment at the upper Aptian using realistic boundary conditions and a fully coupled ocean atmosphere model, FOAM. Given the uncertainties on the boundary conditions, a suite of sensitivity experiments is performed (bathymetry, topography).

\section{Methods}

The model experiments were performed with the Fast OceanAtmosphere model (FOAM) developed by Jacob (1997). FOAM successfully simulates many aspects of the presentday climate and compares well with other contemporary medium-resolution climate models; it has also been used previously to investigate Cretaceous and Neoproterozoic climates (Donnadieu et al., 2006; Poulsen et al., 2001, 2002, 2003). This model is a fully coupled ocean-atmosphere general circulation model. The atmosphere component has a horizontal resolution of $\mathrm{R} 15\left(4.5^{\circ}\right.$ latitude $\times 7.5^{\circ}$ longitude, approximately $499 \mathrm{~km} \times 817 \mathrm{~km}$ ) and 18 levels in the vertical. The ocean component has 24 vertical levels and a horizontal resolution of $1.4^{\circ}$ latitude $\times 2.8^{\circ}$ longitude, approximately $155 \mathrm{~km} \times 305 \mathrm{~km}$. A coupler links the ocean and atmospheric models. The experiments were integrated for $1000 \mathrm{yr}$ without flux corrections or deep ocean acceleration. During the last $100 \mathrm{yr}$ of model integration, there is no apparent drift in the upper ocean (between the surface and $300 \mathrm{~m}$ depth), and less than $0.05^{\circ} \mathrm{C} \mathrm{yr}^{-1}$ change in globally averaged ocean temperature. The results discussed above correspond to the mean climate averaged over the last $50 \mathrm{yr}$.

Numerical climate modeling is subject to uncertainties, as simulations are highly dependent on the prescribed boundary conditions. Here we attempt to provide our model with boundary conditions that are constrained at best for the Aptian. First, all simulations share the early Aptian global paleogeography of Sewall et al. (2007) in which we slightly modified the mountain reliefs and the shorelines (Fig. 2). The elevation of the Andes was fixed to $900 \mathrm{~m}$ a.s.l. (above sea-level) due to the presence of back-arc basins with marine sedimentation along the Andes (Legarreta and M. A., 1991; Uliana and Legaretta, 1993), involving a relatively low relief. Shoreline along Argentina was also amended, according to several sedimentological studies involving alluvial to lacustrine depositional environment in several basins located along the Argentina margin, i.e. the San Jorge basin (Homovc 
Table 1. Description of the different simulations.

\begin{tabular}{lrrllll}
\hline & $\begin{array}{r}\text { Topography } \\
(\mathrm{m})\end{array}$ & $\begin{array}{r}\text { Bathymetry } \\
(\mathrm{m})\end{array}$ & $\begin{array}{l}\text { watershed } \\
\text { boundaries }\end{array}$ & $\begin{array}{l}\mathrm{CO}_{2} \\
(\mathrm{ppm})\end{array}$ & Vegetation & $\begin{array}{l}\text { Orbital } \\
\text { parameters }\end{array}$ \\
\hline TopoA & 900 & 40 & $\begin{array}{l}\text { Diverge } \\
\text { outside of } \\
\text { the Central } \\
\text { segment }\end{array}$ & 1120 & Sewall et al. (2007) & $\begin{array}{l}\text { Default } \\
\text { Exc: } 0.0167 \\
\end{array}$ \\
& 900 & 200 & $\begin{array}{l}\text { Diverge } \\
\text { Obl: } 23.446\end{array}$ & 1120 & Sewall et al. (2007) & - \\
Bathy & 900 & 40 & Converge & 1120 & Sewall et al. (2007) & - \\
TopoB & 3000 & 40 & Diverge & 1120 & Sewall et al. (2007) & - \\
TopoHigh & & & & & & \\
\hline
\end{tabular}

et al., 1995; Paredes et al., 2007), the Valdez-Rawson basin (Milani and Thomaz Filho, 2000; Otis and Schneidermann, 2000), the Salado basin (Milani and Thomaz Filho, 2000), and the Colorado basin (Milani and Thomaz Filho, 2000). Shorelines along Africa were also modified according to paleogeographic maps of Guillocheau et al. (2008). The last change concerns the Central segment that was still continental on the reconstruction of Sewall et al. (2007). However, the salt from the Central segment was deposited in a marine setting but during the late Aptian rather than the early Aptian. In order to account for the fact that we want to simulate the late Aptian time period, we have modified the shorelines along the brazilian margin by changing some land points into oceanic points. From this we ran four experiments to test the impact of topography, surface water routing, and bathymetry on global and regional climate. Table 1 summarizes the detailed boundary conditions of the four simulations. First, the configuration of the watersheds was tested with rift shoulders height fixed to $900 \mathrm{~m}$ a.s.l. and a shallow bathymetry of $40 \mathrm{~m}$ in the Central segment to get as close as possible to shallow conditions, and to allow the stability of the model. The catchments of the rift shoulders were imposed to be directed outside of the Central segment in a first simulation (TopoA), and towards the Central segment in a second run (TopoB, see Table 1). In a second time, and because of the uncertainties on the paleobathymetry during the evaporites deposition, bathymetry was deepened and fixed to $200 \mathrm{~m}$ in the Central segment (Bathy). Finally, the rift altitude was changed to $3000 \mathrm{~m}$ a.s.l. (Topohigh). In all other aspects, the boundary conditions were identical. The atmospheric $\mathrm{CO}_{2}$ was kept constant and fixed at 1120 ppm, a high value typical of the Cretaceous (Royer et al., 2004). The solar constant was fixed to $1351.6 \mathrm{~W} \mathrm{~m}^{-2}$ according to the stellar evolution predicted by Gough (1981). Earth orbital parameters were set to present-day values. The vegetation was imposed according to Sewall et al. (2007).

\section{Results}

\subsection{Salinity}

Simulated surface salinity within the central segment varies strongly with the model settings used (Fig. 3). In TopoA simulation, it ranges from 35 to $40 \mathrm{psu}$. The highest values are recorded at $18^{\circ} \mathrm{S}$, in the middle of the segment. Salinity values simulated in TopoB are far lower than TopoA, ranging from 20 to 35 psu (Fig. 3). Runoff, similar to the TopoA simulation, is in this case directed inside the Central segment and is much higher in the north than in the south. This input of fresh water in the segment explains the lower values of salinity. In the Bathy case (Fig. 3), simulated salinities are very similar to those from the TopoA simulation, but slightly lower in the south. In this area, maximum values are not higher than $39.1 \mathrm{psu}$. Salinity decreases gradually towards the north of the Central segment, reaching values of about 35.7 psu. Finally, with the establishment of a large rift relief in the TopoHigh simulation (Fig. 3) and a watershed configuration similar to the TopoA simulation, the north-south salinity gradient in the Central segment is greater than for the TopoA simulation. Indeed, in TopoHigh run, salinities exceed $40 \mathrm{psu}$, and decrease sharply to the north, reaching values close to $31 \mathrm{psu}$. This is the result of the modifications simulated in the runoff distribution. In details, runoff increases largely to the northwest of the rift $\left(400 \mathrm{~cm} \mathrm{yr}^{-1}\right.$ to the northwest and 0 to $10 \mathrm{~cm} \mathrm{yr}^{-1}$ in the East). Whatever the bathymetry, topography or configuration of watersheds, the North Central segment still has lower salinity values. Further north, in the equatorial segment, the salinity is very low in all simulations and reflects the runoff routing, directed to the north. Finally, high surface salinity is recorded to the SouthWest of the Eurasia continent (not shown), until 41 psu, and is in good agreement with the evaporites referenced here (Chumakov et al., 1995). 

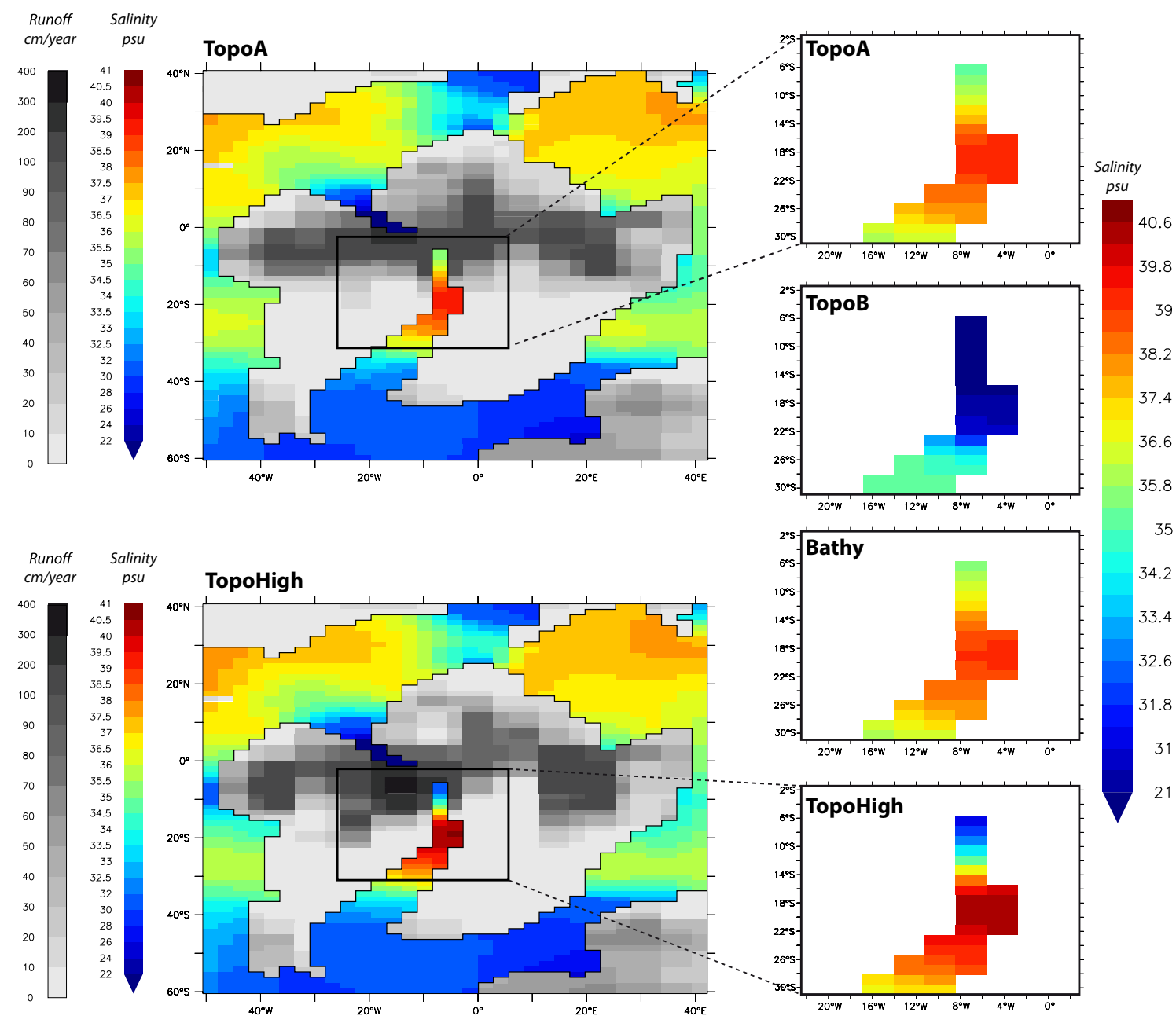

Fig. 3. Annual surface salinity (psu) and annual runoff $\left(\mathrm{cm} \mathrm{yr}^{-1}\right)$ for the TopoA, TopoB, Bathy and TopoHigh runs. The white to black color scale represents the runoff and the blue to red scale the salinity.

\subsection{Climate}

We quantify the aridity of the climate with the precipitation minus evaporation diagnostic $(P-E)$. In Fig. 3 we present annual $P-E$ distribution for the TopoA and the TopoHigh runs. Indeed, the general pattern of the mean annual $P-E$ is similar for the TopoA, TopoB and Bathy runs. For these three runs, the North of America and Africa is affected by a strongly positive $P-E$, around $5 \mathrm{~mm}^{-1}{ }^{-1}$, indicating that precipitations dominate. On the contrary, the South of these continents is characterized by a negative $P-E$, around $-1 \mathrm{~mm} \mathrm{day}^{-1}$. The Central segment, located between 0 and $22^{\circ} \mathrm{S}$, is also affected by both of these climatic regimes. In the northern part, the Central segment is characterized by positive $P-E$ values, ranging from 1 to $4 \mathrm{~mm} \mathrm{day}^{-1}$. The southern part of the Central segment presents negative values of $P-E$, to $-2.5 \mathrm{~mm} \mathrm{day}^{-1}$. The establishment of a high rift relief (Fig. 4b) induces a more positive $P-E$ in the North of the basin, near $6 \mathrm{~mm} \mathrm{day}^{-1}$, and slightly more negative $P-E$ in the South, around $-3 \mathrm{~mm} \mathrm{day}^{-1}$. Northern Gondwana $\left(20^{\circ} \mathrm{S}\right.$ to $\left.20^{\circ} \mathrm{N}\right)$ is affected by a strong rainfall seasonality driven by the latitudinal shift of the ITCZ (Fig. 5). The positive value of $P-E$ to the North of the Central segment is caused by intense rainfalls that occur during the austral spring, summer and autumn (Fig. 5c). This is due to the shift of the Intertropical Convergent Zone (ITCZ) over the equatorial areas. The North of the Central segment, near the equator, is located below the ITCZ and is then characterized by high precipitations, up to 12 to $14 \mathrm{~mm}$ day $^{-1}$ in austral summer and autumn seasons (Fig. 5c). However, during the austral winter, the precipitation are weak, with less than $2 \mathrm{~mm} \mathrm{day}^{-1}$ (Fig. 5a), because of the shift of the ITCZ to northern latitudes. The South of the Central segment, away from the equator, is less affected by the seasonal oscillation of the ITCZ and is characterized by weak rainfall in all the year, less to $4 \mathrm{~mm} \mathrm{day}^{-1}$ (Fig. 5a). During the austral winter and spring, the rainfalls are even close to $0 \mathrm{~mm} \mathrm{day}^{-1}$ here (Fig. 5e). Precipitations over lands are 
dependent on the moisture sources and on the potential orographic effects. During austral autumn and winter, moisture is carried by NE and SE trade winds coming from the Tethys ocean. During summer, moisture comes from the NE trade winds from the Tethys ocean, but also from south-westerly winds from the Pacific ocean. In TopoA experiment, mountains are reduced over the Gondwana due to low rift relief and Andes altitudes $(900 \mathrm{~m})$. Whatever the season, the moisture belt is then continuous over the continent (Fig. 5a and c), the relief being too low to act as a topographic barrier. Important changes appear in the intensity and the geographic repartition of rainfalls in the TopoHigh case, when a high rift relief is used. Rainfall is intensified over the rift relief, reaching up to $20 \mathrm{~mm} \mathrm{day}^{-1}$ during summer and autumn seasons, and the humid climatic belt appears discontinuous over the African continent (Fig. 5d). However, the source of moisture does not change. The onset of high rift shoulders causes high atmospheric rising motion (convection) over the rift relief as well as income of moisture from the ocean (advection), eventually causing high rainfalls over the area. Strong moisture advection linked to temperature and pressure gradients between the ocean and the continent, associated with reversal winds, are typical from monsoon systems, and have been well described by Fluteau et al. (1999) for the evolution of the Asian monsoon with the uplifts of the Tibetan plateau and of the Himalayas. The high rift shoulders trigger more reduced salinities in the northern part of the Central segment (down to $12 \mathrm{psu}$, as previously shown in Fig. 3), where the rainfall reach $16 \mathrm{~mm} \mathrm{day}^{-1}$ (Fig. 5d and f). However, in the southern part, precipitations are reduced, less than $1 \mathrm{~mm}$ day $^{-1}$, and the salinities increase slightly, up to $40 \mathrm{psu}$ (Fig. 3). The main pattern of precipitation in the Central segment is similar between a no-rift relief simulation and a rift relief, but the north-south salinity gradient is strengthened with high rift shoulders. The rainfalls involved with the orographic effect of high rift shoulders trigger a dilution of the brine, causing even less favourable salinity conditions in the north of the Central segment. However, whatever the rift relief, the Central segment is affected by seasonal rainfall due to the movement of the ITCZ, with pronounced dry and wet seasons. The seasonal shift of the ITCZ defines the latitudinal boundaries of wet and dry areas. Figure $4 \mathrm{e}$ and $\mathrm{f}$ show that whatever the season, rainfalls are more abundant in the north of the Central segment than in the south for all seasons.

\section{Discussion}

\subsection{Role of catchment divide and runoff}

The results of our model simulations highlight the role of paleogeographic configuration on salinity in the Central segment. The simulations have shown the role of the runoff on the dilution of the evaporitic basin, here the Central Segment. When runoff is directed toward the Central segment, high rainfalls near the equator induce low salinities. Conversely, when the catchment divide is reverted and runoff is directed outside of the Central segment, the salinities are much higher, and more favorable to the deposition of the salt. However, the maximum values do not exceed $40 \mathrm{psu}$. This remains much lower values than those reported by Holser (1979) to precipitate medium to highly soluble salts (i.e. between 370 and $400 \mathrm{psu}$ ). This difference is probably due to the resolution of the model which does not allow to represent an isolated basin submitted to marine influence, as a sabkha environment. A depth of $40 \mathrm{~m}$ cannot allow a supersaturation of the water as intense as in a sabkha, and to obtain salinites close to those expected in this case. However, although the bathymetry is not representative of a sabkha environment, high values are simulated in the Central segment, well above the average surface salinity of the global ocean of our simulations ( $35.29 \mathrm{psu}$ ), reflecting favorable conditions for the development of evaporites. These results suggest that reduced freshwater inflows in the central segment are required to allow the formation of evaporites at these latitudes. Several factors can reduce freshwater inflows. Narrow and steep rift shoulders would allow limiting the runoff on the watershed, because of their low drainage surface. Another hypothesis is an inversion of the catchment divide, before the deposition of the salt, and a redirection of the runoff routing outside of the Central segment. To this end, an elevation of the relief is necessary to change runoff flow to the opposite direction. This elevating could be triggered by an exhumation phase expected in the end of the rift evolution, before the break up, involving the lower crust (Aslanian et al., 2009). Indeed, this exhumation phase, which evolves in an elevated position during the thinning process (Aslanian et al., 2009; Moulin et al., 2005) can trigger an additional uplift of the margin (Moulin et al., 2012). In addition, a large unconformity is recorded throughout the Central segment, prior to the filing of salt (Braccini et al., 1997; Caixeta et al., 2007; Campos Neto et al., 2007; Grosdidier et al., 1996; Mbina Mounguengui et al., 2008; Milani et al., 2007; Rangel et al., 2007; Teisserenc and Villemin, 1990; Winter et al., 2007). This unconformity could be a reflection of a brief elevation of the terrain at the origin of this erosion phase, and could trigger a reversal of the polarity of the watershed, and a redirection of the runoff. This hypothesis is consistent with the geochemical study of Harris (2000) that highlights, with parameters providing information on source terranes with a $\mathrm{Al}_{2} \mathrm{O}_{3} / \mathrm{TiO}_{2}$ ratio, a shift in the provenance of sediment. This suggests a significant reorganization of the drainage system at the end of the rift, before the salt deposit. Whatever the active mechanism, a limit of the runoff within the central segment is imperative for the establishment of salt.

\subsection{Central segment: south versus north}

Our simulations have revealed a latitudinal climatic pattern between a wet northern part with low salinities, and a 

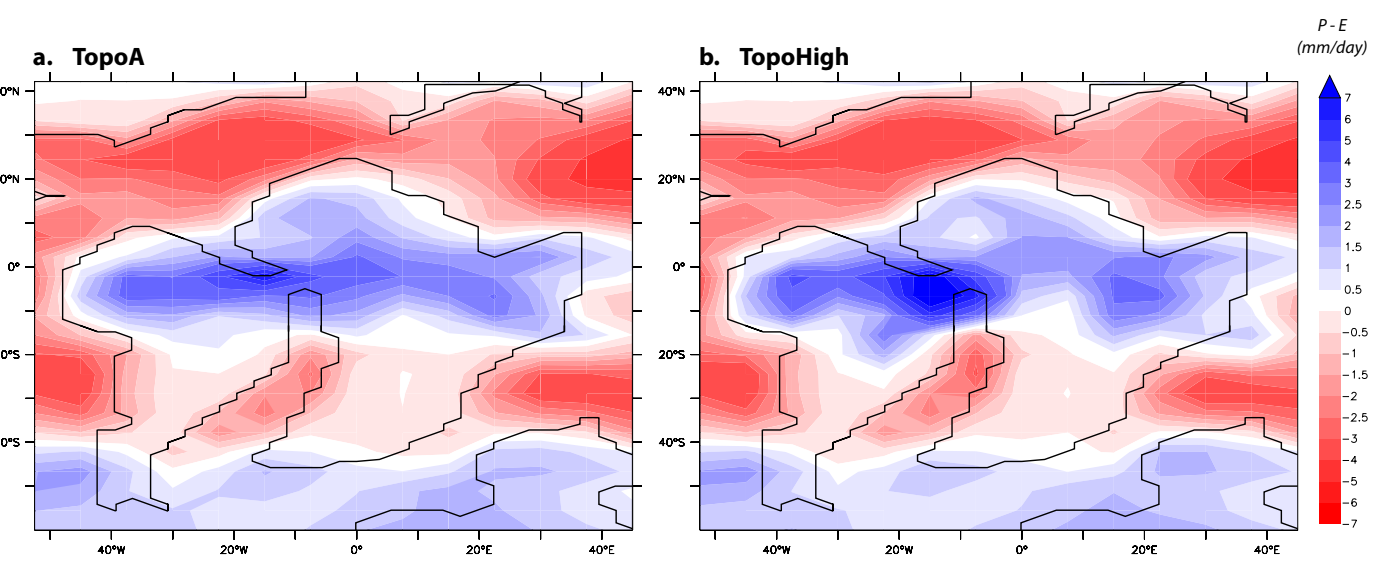

Fig. 4. Annual $P-E$ (precipitation minus evaporation) for the TopoA and the TopoHigh simulations. Positive blue (negative red) colors represent precipitation (evaporation) mechanisms.

southern part more arid with higher salinities. During the rifting, in Barrmian time, the Central segment was a mainly lacustrine environment where organic matter was deposited (Braccini et al., 1997; Caixeta et al., 2007; Campos Neto et al., 2007; Grosdidier et al., 1996; Mbina Mounguengui et al., 2008; Milani et al., 2007; Rangel et al., 2007; Teisserenc and Villemin, 1990; Winter et al., 2007). According to a recent study (Brownfield and Charpentier, 2006), the distribution of the quality and type of source rocks in the Central segment allows to define climatic conditions. According to the authors, pre-salt hypersaline lacustrine source rocks, pre-salt oils with hyper-saline biomarkers and high abundance of lacustrine carbonates are recorded to the south of the presentday Congo River, and are the witness of a dry climate. On the contrary, to the North, the authors identified the presence of mixed type I-III source rocks rather indicative of more humid conditions, and coherent with more clastic sediments in this area, compared to the South. Thus, the latitudinal climatic pattern simulated is consistent with the sedimentary record from the Central segment before the salt deposit.

The distribution of evaporites in the central segment is also not homogeneous, and presents a latitudinal mineralogic distribution. As mentioned above, the North Central segment is mainly characterized by the presence of moderately to highly soluble salts (sylvite, carnaillite, and bishofite tachyhydrite, also called "potash salt"), while the southern part is characterized by more common salts and less soluble gypsum and halite type. The formation of the different evaporitic minerals results from the evaporation of seawater, which causes the precipitation of an ordered sequence of increasing mineral solubility (Braitsch, 1971; Harvie et al., 1984; Usiglio, 1849). According to this sequence, the precipitation of gypsum begins when seawater is concentrated 3.8 times, and halite where concentrations exceed 10 times that of seawater. Sulfate salts of magnesium appear to 70 times the concentration of seawater, and finally potassium salts only when concentration exceeds 90 times that of seawater (Borchert and
Muir, 1964; McCaffrey et al., 1987). Thus, potassium salts such as sylvite and carnaillite, highly soluble, are the last to be formed during the evaporation of seawater. Our simulations raise a paradox, since the most soluble and concentrated salts are present in the North Central segment, where conditions are wetter and less favorable, while the less soluble evaporites located in the South, are found under favorable conditions to their development. Thus, if in the South, the conditions did not exceed the crystallization of halite in the sequence of evaporation, a simple climatic control seems insufficient to explain the presence of highly soluble evaporites in the northern part. A second controlling factor seems essential to explain the unusual presence of highly soluble salts. The hypothesis of a $\mathrm{CaCl}_{2}$ enrichment of the brines, by hydrothermal water-rock interaction could explain the presence of these highly soluble salts. Hardie (1990) proposed this hypothesis to explain the huge amounts of calcium imposed by the high thickness of the tachyhydrite, that seawater could not provide. The enrichment by hot hydrothermal brines could result in the development of a proto-oceanic crust as spreading centers in the North of the Central segment. The brine in the evaporitic basin would have been in contact with seafloor basalts, and could have been enriched in calcium by the alteration of volcanic materials, with high content of plagioclases. This interpretation is in good agreement with the volcanism identified to the North of the Central segment, as Seaward dipping reflectors (Mohriak et al., 1995). Moreover, the presence of high concentrations of $\mathrm{Pb}, \mathrm{Zn}, \mathrm{Fe}$, and $\mathrm{Mn}$ in the salt is a good indicator of hydrothermal brine (Wardlaw and Nicholls, 1972). These upwelling brines, characterized by an unusual composition and a high salinity, are important contributors to solute in the evaporitic basin, explaining the presence of the unusual salt. Furthermore, recent papers mention that seawater chemistry was not constant over the past $600 \mathrm{Myr}$ (Hardie, 1996; Spencer and Hardie, 1990), and has oscillated between (1) Na-K-Mg-Ca-Cl and (2) Na-K-Mg$\mathrm{Ca}-\mathrm{Cl}-\mathrm{SO}_{4}$ types, controlled by fluctuations of the mid-ocean 

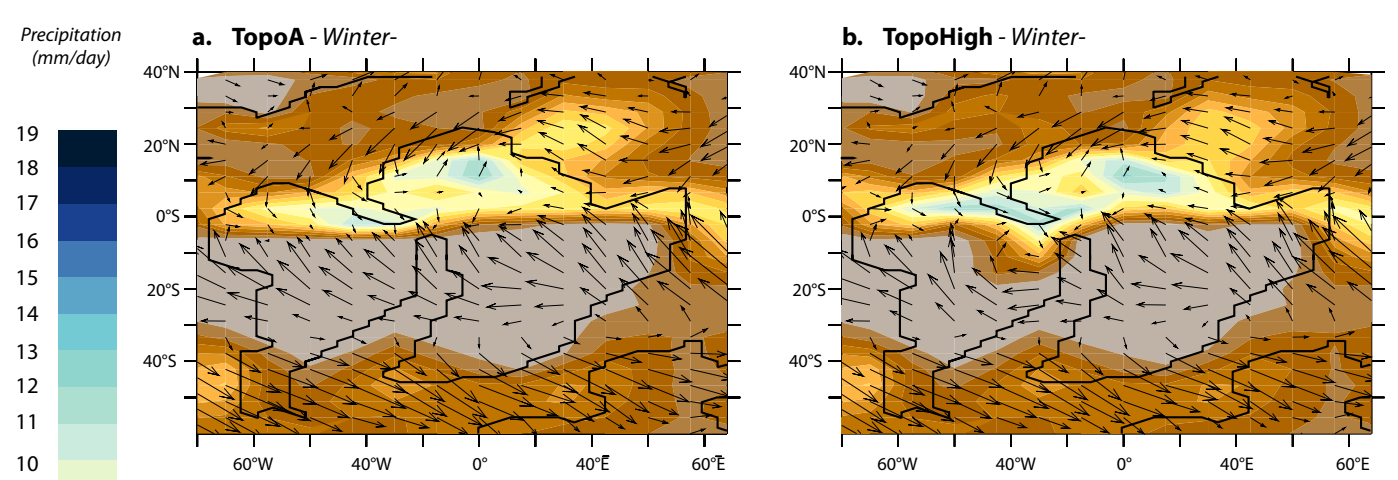

c. TopoA - Summer

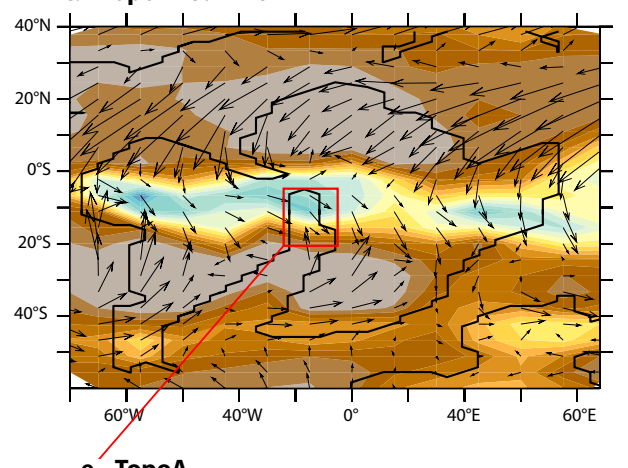

d. TopoHigh - Summer
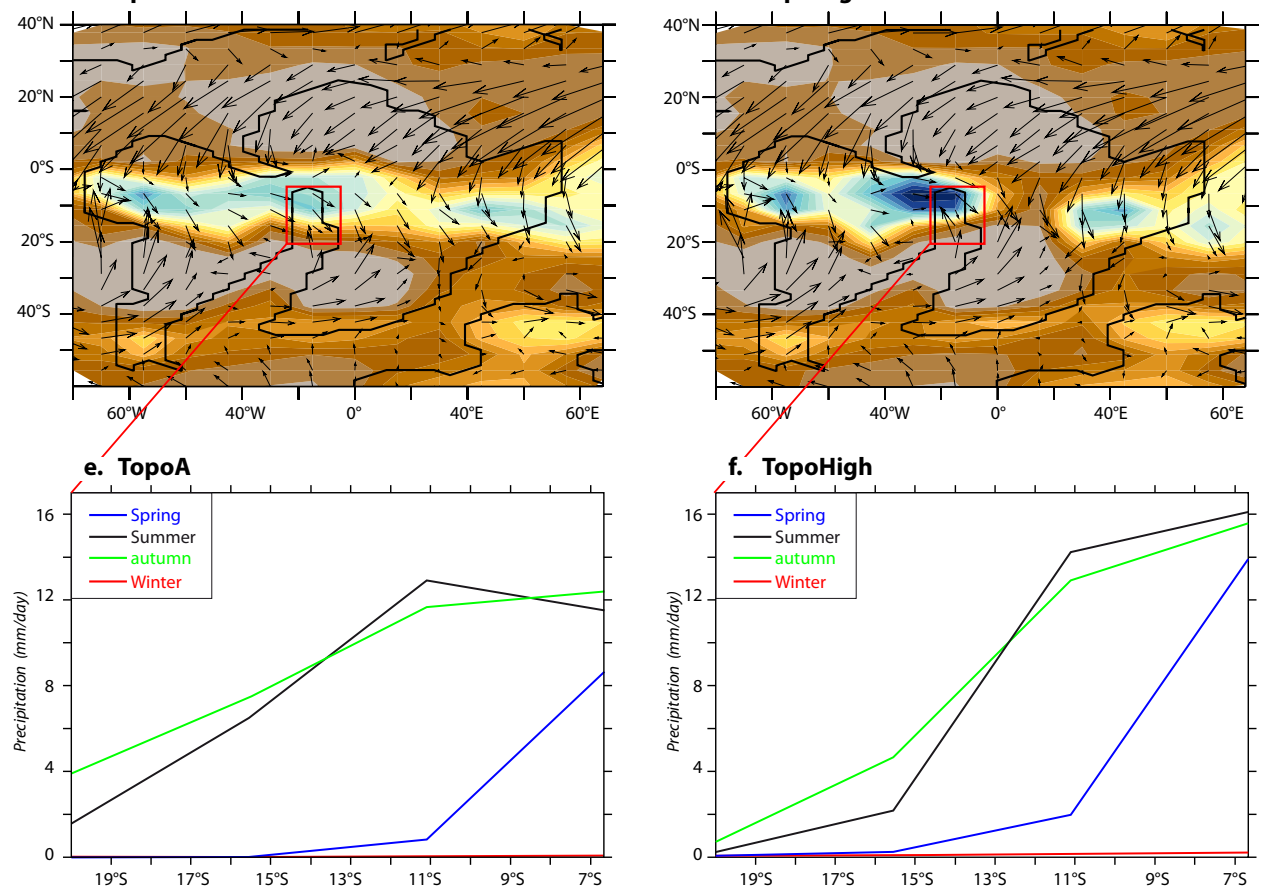

Fig. 5. Seasonal average precipitations $\left(\mathrm{mm} \mathrm{day}^{-1}\right.$ ). (a) For the TopoA in austral winter (DJF); (b) for the TopoHigh in austral Winter; (c) for the TopoA in austral summer (JJA); (d) for the TopoHigh in austral summer. Latitudinal evolution of the seasonal average precipitation $\left(\mathrm{mm} \mathrm{day}^{-1}\right)$ in the Central segment (between $5^{\circ} \mathrm{W}$ and $\left.25^{\circ} \mathrm{W}\right)(\mathbf{e})$ for the TopoA and (f) for the TopoHigh.

ridge hydrothermal brine flux (Hardie, 1996; Spencer and Hardie, 1990) or combined with the dolomitization of the platform carbonate (e.g. Holland et al., 1996). Such changes in seawater chemistry controlled the type and the order of potash minerals (Warren, 2006), with two potash endmembers, (1) calcium chloride and (2) Mg-sulphate brines. According to Brennan and Lowenstein (2002) and Lowenstein et al. (2003), the seawater in the Early Cretaceous had a $\mathrm{CaCl}_{2}$ - rich composition, which does not precipitate the $\mathrm{MgSO}_{4}$ potash salts, but rather the sylvite, carnaillite, bishofite and tachyhydrite potash salts (Warren, 2006). This water chemistry has probably favored the presence of these evaporites in the Central segment, and may explain the absence of $\mathrm{MgSO}_{4}$ salts. Thus, these two combined control factors (upwelling brines and ocean chemistry) would explain the formation of these potash evaporites, under a less favorable climate.

To summarize, while the climate may have been the main factor controlling the evaporites deposition in the South of the Central segment, the evaporites deposited in the North of the Central segment may be due to peculiar geodynamic conditions. However, we can not determine to what extent the hydrothermal influences compensate the aridity of the climate. Furthermore, although the climate of the Central segment seems always more humid to the North, the high variability of the regime of the seasonal precipitation probably played a role in the preservation of evaporites. This seasonality is also recorded in the equatorial segment, further North, where evaporites are also recorded and mainly composed of anhydrite and gypse (Davison, 2007; Paz et al., 2005; Zalan, 2007). The most soluble salt is the halite (Conde et al., 
2007; Davison, 2007), and no potash salt is recorded in this area (Fig. 1a). A dry season induced by the seasonality could be sufficient to allow the formation of evaporites and their preservation.

\subsection{Rift relief}

Many uncertainties remain about the altitude of the rift flanks. The establishment of a rift relief close to $3000 \mathrm{~m}$ high, an extreme value, causes the appearance of important permanent precipitation in the North. A very rainy area sits west of the rift, all year, resulting from the establishment of an important convective cell near the rift, similar to the monsoon atmospheric dynamics observed by Fluteau et al. (1999). The establishment of a high relief rift created conditions less favorable in the north for the evaporites deposition. During the deposition of salt, it is possible that the relief was reduced, and that it no longer played the role of topographic barrier. Indeed even when the runoff is directed outside of the Central segment, precipitation induced by orographic effect over the rift leads to lower salinities in the basin. A reduction of the rift relief is consistent with the study of spores and pollens from the North of the Central segment (Grosdidier et al., 1996) which highlights the evolution of specimens characterizing a significant relief landscape in a humid climate to specimens depicting a flattened relief in a more arid climate just before the salt deposit. Furthermore, Harris (2000) conducted a geochemical study on rift sediments of the Central segment, and highlighted carbon isotopic variations of carbonates reflecting a greater contribution of decomposed vegetation just before the salt deposit. He interprets this shift as a consequence of the decrease of the slope in the context of topographically degrading rift allowing the development of thicker soils. However, as mentioned earlier, an additional uplift is expected to explain the change in the drainage basin. Thus, despite the uncertainties in the altitude of the rift, it is very likely that it has been greatly reduced but not completely flattened, and that a slight relief persists during the deposition of the salt. Finally, on the contrary to the topography, a deepening of the bathymetry does not seem to be a major factor controlling the salinity in the Central segment.

\subsection{Climatic belt}

We show that during the South Atlantic opening in Aptian time, the Central segment was located near a humid climatic belt. These modelling results are not in agreement with paleoclimatic maps of Chumakov et al. (1995) and Scotese et al. (1999), which indicate an arid climate over all Africa and America. According to Chumakov, the humid climatic belt set up during the Albian time. To achieve these paleoclimatic maps these authors used climate indicators such as evaporites, bauxites, tillite and mapped the positions of the various major climate zones. For the evaporites, our results show that although commonly associated with an arid climate, they can be combined with various other mechanisms and lead to hedge interpretations. In the case of the South Atlantic, although evaporites are listed across the Central segment, we show that they are not all representative of an arid climate and that it is likely that climate humid belt was present over the Gondwana from the Aptian. According to recent publications (Lentini et al., 2010), these humid conditions would have even played a role in the nature and the distribution of the sedimentary fill of rift basins of the central segment, influencing the type and quality of the source rocks and clastic facies distribution and carbonate. Along the Equator, our model results show high precipitation rates, which are overestimated regarding the data (Spicer et al., 1993; Beerling, 2000; Chumakov et al., 1995; Sewall et al., 2007). This bias is very likely linked to the prescribed zonal vegetation, which relies on present-day Plant Functionnal Types (PFTs), not adapted to the characteristics (e.g. evapotranspiration rates) of Cretaceous vegetation. Such a feature has been highlighted in recent studies and should be considered in the future development of past vegetation models (Boyce and Lee, 2010). Indeed, Boyce et al. (2009) highlighted in their study that the capacity of flowering to transpire water, which is an important contributor to rainfall, was not constant through time but increased. According to a later study (Boyce and Lee, 2010), the increase of transpiration capacity induced a rise of moisture recycling and an overall increase of rainfall. Thus such changes in the PFTs can modify the climate, but are not considered at present by the model. Despite these limitations, we are able to provide new quantifications of the climate at Aptian time. A subsequent study by coupling a vegetation model, however, could refine these results.

\section{Conclusions}

In this paper, we quantify the role of paleogeography on the development of evaporites through changes of runoff routing and topography. To allow the deposition of the Aptian salt, a decrease of the fresh water input via the runoff is required to obtain high salinities. However, because of the presence of a humid climatic belt north of the Central segment, the conditions remain not favorable. This raises a paradox, because the more soluble and more volatile salts are recorded to the North. Here, a geodynamic control factor is suspected, through the establishment of hydrothermal flux and contamination of the brines, to allow the formation of the highly soluble salt. On the other hand, in the south of the Central segment, the climatic control factor is likely, since conditions are favorable. These evaporites of the South Atlantic are thus not all associated with an arid climate, and cannot be used as paleoclimatic indicator in this case. It is very likely that, despite the presence of evaporites, a humid climatic belt near the equator was present over the Gondwana from the Aptian. In this sense, it suggests it is not the connection between the North and South Atlantic during Albian time that controls the apparition of this humid climatic belt. Finally, our simulations suggest that during 
the Aptian salt deposition, the relief was probably partially eroded and did not act as topographic barrier.

Edited by: H. Brinkhuis

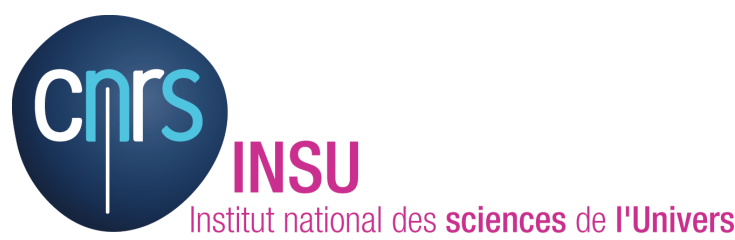

The publication of this article is financed by CNRS-INSU.

\section{References}

Aslanian, D., Moulin, M., Olivet, J. L., Unternehr, P., Matias, L., Bache, F., Rabineau, M., Nouze, H., Klingelheofer, F., Contrucci, I., and Labails, C.: Brazilian and African passive margins of the central segment of the South Atlantic Ocean; kinematic constraints, Tectonophysics, 468, 98-112, 2009.

Asmus, H. E., and Ponte, C. F.: The Brazilian marginal basins, edited by: Nairn, E. A. M. and Stelhi, F. G., Plenum Press, New York, 87-133, 1973.

Austin, J. A. and Uchupi, E.: Continental-oceanic crustal transition off Southwest Africa, AAPG Bulletin, 66, 1328-1347, 1982.

Beerling, D. J.: Global terrestrial productivity in the Mesozoic Era, in: Climates: Past and Present, edited by: Hart, M. B., Geological Society, London, Special Publications, 181, 17-32, 2000.

Belmonte, Y., Hirtz, P., and Wenger, R.: The salt basins of the Gabon and the Congo (Brazzaville); a tentative palaeogeographic interpretation, in: Salt Basins around Africa, edited by: Ion, D. C., The institute of Petroleum, London, 55-74, 1965.

Borchert, H. and Muir, R. O.: Salt deposits; the origin, metamorphism and deformation of evaporites, Van Nostrand, London, Princeton, N.J., 1964.

Boyce, C. K. and Lee, J.-E.: An exceptional role for flowering plant physiology in the expansion of tropical rainforests and biodiversity, P. Roy. Soc. Lond. B, 277, 3437-3443, 2010

Boyce, C. K., Brodribb, T., Feild, T. S., and Zwieniecki, M. A.: Angiosperm leaf vein evolution was physiologically and environmentally transformative, P. Roy. Soc. Lond. B, 276, 1771-1776, 2009.

Braccini, E., Denison, C. N., Scheevel, J. R., Jeronimo, P., Orsolini, P., and Barletta, V.: A revised chrono-lithostratigraphic framework for the pre-Salt (Lower Cretaceous) in Cabinda, Angola, Bull. Cent. Rech. Explor. Prod. Elf-Aquitaine, 21, 125-151, 1997.

Braitsch, O.: Salt Deposits, Their Origin and Composition, Minerals, Rocks and Mountains 4, Springer, New York, 1971.

Brennan, S. T. and Lowenstein, T. K.: The major-ion composition of Silurian seawater, Geochim. Cosmochim. Acta, 66, 2683-2700, 2002.

Brognon, G. P. and Verrier, G. R.: Oil and geology in Cuanza Basin of Angola, AAPG Bulletin, 50, 108-158, 1966.
Brownfield, M. E. and Charpentier, R. R.: Geology and total petroleum systems of the West-Central Coastal Province (7203), West Africa, US Geological Survey, Reston, VA, USA, 2006.

Butler, L. W.: Shallow Structure of the Continental Margin, Southern Brazil and Uruguay, Geol. Soc. Am. Bull. , 81, 1079-1096, 1970.

Caixeta, J. M., Milhomem, P. D. S., Witzke, R. E., Dupuy, I. S. S., and Gontijo, G. A.: Bacia de Camamu, Boletim de Geociências da PETROBRAS, 15, 455-461, 2007.

Campos Neto, O. P. D. A., Lima, W. S., and Gomes Cruz, F. E.: Bacia de Sergipe-Alagoas, Boletim de Geociências da PETROBRAS, 15, 405-415, 2007.

Chumakov, N. M., Zharkov, M. A., Herman, A. B., Doludenko, M. P., Kalandadze, N. N., Lebedev, E. L., Ponomarenko, A. G., and Rautian, A. S.: Climatic belts of the mid-Cretaceous time, Stratigr. Geol. Correl., 3, 241-260, 1995.

Clarke, L. and Jenkyns, H.: New oxygen isotope evidence for longterm Cretaceous climatic change in the Southern Hermisphere, Geology, 27, 699-702, 1999.

Conde, C. C., Lana, C. C., Roesner, H. E., Morais Neto, J. M., and Dutra, C. D.: Bacia do Ceara, Boletim de Geociências da PETROBRAS, 15, 347-355, 2007.

Davison, I.: Tectonics and hydrocarbon distribution along the Brazilian South Atlantic margin, in: The Oil and Gas Habitats of the South Atlantic, edited by: Cameron, N. R. and Clure, V. S., Geol. Soc., London, Special Publications, 153, 133-151, 1999.

Davison, I.: Geology and tectonics of the South Atlantic Brazilian salt basins, in: Deformation of the Continental Crust: The Legacy of Mike Coward, edited by: Ries, A. C., Butler, R. W. H., and Graham, R. H., Geol. Soc., London, Special Publications, 272, 345-359, 2007.

De Lurio, J. L. and Frakes, L. A.: Glendonites as a paleoenvironmental tool: implications for early Cretaceous high latitude climates in Australia, Geochim. Cosmochim. Acta, 63, 1039-1048, 1999.

de Ruiter, P. A. C.: The Gabon and Congo basins salt deposits, Econ. Geol. Bull. Soc. Econ. Geol., 74, 419-431, 1979.

Donnadieu, Y., Pierrehumbert, R., Jacob, R., and Fluteau, F.: Modelling the primary control of paleogeography on Cretaceous climate, Earth Planet. Sc. Lett., 248, 426-437, 2006.

Doyle, J. A., Biens, P., Doerenkamp, A., and Jardiné, S.: Angiosperm pollen from the Pre-Albian Lower Cretaceous of equatorial Africa, Bull. Cent. Rech. Explor. Prod. Elf-Aquitaine, 1, 451-473, 1977.

Doyle, J. A., Jardiné, S., and Doerenkamp, A.: Afropolis, un nouveau genre de pollen d'Angiosperme précoce, avec de données sur la palynostratigraphie et les paléoenvironnements du Crétacé du Nord-Gondwana, Bull. Cent. Rech. Explor. Prod. ElfAquitaine, 6, 39-117, 1982.

Fluteau, F., Besse, J., and Ramstein, G.: Simulating the evolution of the Asian monsoon during the past 30 million years using an atmospheric general circulation model, J. Geophys. Res., 104, 11995-12018, 1999.

Frakes, L. and Francis, J. E.: A guide to Phanerozoic cold polar climates from high-latitude ice-rafting in the Cretaceous, Nature, 333, 547-549, 1988. 
Frakes, L. A.: Estimating the global thermal state from Cretaceous sea surface and continental temperature data, in: Evolution of the Cretaceous ocean-climate system, edited by: Barrera, E. and Johnson, C., Geological Society of America, Special Paper, 332, 49-57, 1999.

Gough, D. O.: Solar interior structure and luminosity variations, Solar Phys., 74, 21-34, 1981.

Grosdidier, E., Braccini, E., Dupont, G., Moron, J. M., and Université d'Angers, F.: Non-marine lower Cretaceous biozonation of the Gabon and Congo Basins, in: Géologie de l'Afrique et de l'Atlantique sud, edited by: Jardine, S., De Klasz, I., and Debenay, J.-P., Elf Aquitaine Memoire, 16, 67-82, 1996.

Guillocheau, F., Rolland, N., Colin, J.-P., Robin, C., Rouby, D., Helm, C., Dauteuil, O., and Tiercelin, J.-J.: Palaeogeography and deformation of Africa through late Jurassic-Cretaceous times, International Geological Congress, 33, Oslo, Resumes, 2008.

Hardie, L. A.: The roles of rifting and hydrothermal $\mathrm{CaCl}_{2}$ brines in the origin of potash evaporites; an hypothesis, Am. J. Sci., 290, 43-106, 1990.

Hardie, L. A.: Secular variation in seawater chemistry; an explanation for the coupled secular variation in the mineralogies of marine limestones and potash evaporites over the past $600 \mathrm{~m} \mathrm{y}$, Geology, 24, 279-283, 1996.

Harris, N. B.: Evolution of the Congo rift basin, West Africa; an inorganic geochemical record in lacustrine shales, Basin Res., 12, 425-445, 2000.

Harvie, C. E., Moller, N. E., and Weare, J. H.: The prediction in mineral solubilities in natural waters; the $\mathrm{Na}-\mathrm{K}-\mathrm{Mg}-\mathrm{Ca}-\mathrm{H}-\mathrm{Cl}-$ $\mathrm{SO}_{4}-\mathrm{OH}-\mathrm{HCO}_{3}-\mathrm{CO}_{3}-\mathrm{CO}_{2}-\mathrm{H}_{2} \mathrm{O}$ system to high ionic strengths at 25 degrees C, Geochim. Cosmochim. Acta, 48, 723-751, 1984.

Holland, D. S., Horita, J., and Seyfried, W.: On the secular variations in the composition of phanerozoic marine potash evaporites, Geology, 24, 993-996, 1996.

Holser, W. T.: Mineralogy of evaporites, Mineralogical Society of America Short Course Notes, 6, 211-294, 1979.

Homovc, J. F., Conforto, G. A., Lafourcade, P. A., and Chelotti, L. A.: Fold belt in the San Jorge Basin, Argentina; an example of tectonic inversion, in: Basin Inversion, edited by: Buchanan, J. G. and Buchanan, P. G., Geological Society, London, Special Publications, 88, 235-248, 1995.

Huber, B. T., Hodell, D. A., and Hamilton, C. P.: Middle-Late Cretaceous climate of the southern high latitudes; stable isotopic evidence for minimal equator-to-pole thermal gradients, Geol. Soc. Am. Bull., 107, 1164-1191, 1995.

Jacob, R.: Low frequency variability in a simulated atmosphere ocean system, Ph.D., University of Wisconsin, Madison, 159 pp., 1997.

Legarreta, L. and Uliana, M. A.: Jurassic-Cretaceous marine oscillations and geometry of backarc basin fill, central Argentine Andes, Special Publications of the Internal Association of Sedimentologists, 12, 429-450, 1991.

Lentini, M. R., Fraser, S. I., Sumner, H. S., and Davies, R. J.: Geodynamics of the central South Atlantic conjugate margins; implications for hydrocarbon potential, Petrol. Geosci., 16, 217-229, 2010.

Lowenstein, T. K., Hardie, L. A., Timofeeff, M. N., and Demicco, R. V.: Secular variation in seawater chemistry and the origin of calcium chloride basinal brines, Geology, 31, 857-860, 2003.
Mbina Mounguengui, M., Lang, J., and Guiraud, M.: Sedimentary dynamics and extensional structuring related to early Cretaceous rifting of Neocomian and Barremian deposits of the interior basin of Gabon, J. Afr. Earth Sci., 51, 239-256, 2008.

McCaffrey, M. A., Lazar, B., and Holland, H. D.: The evaporation path of seawater and the coprecipitation of $\mathrm{Br}^{+}$and $\mathrm{K}^{+}$with halite, J. Sediment. Petrol., 57, 928-937, 1987.

Meister, E. M. and Aurich, N.: Geologic outline and oil fields of Sergipe Basin, AAPG Bulletin, 56, 1034-1047, 1971.

Milani, E. J. and Thomaz Filho, A.: Sedimentary basins of South America, in: In-Folo Producao Editorial, Grafica e Programacao Visual: Rio de Janeiro, Brazil, 389-449, 2000.

Milani, E. J., Rangel, H. D., Bueno, G. V., Stica, J. M., Winter, W. R., Caixeta, J. M., and Pessoa Neto, O. d. C.: Bacias sedimentares brasileiras; cartas estratigraficas - Brazilian sedimentary basins; stratigraphic charts, Boletim de Geociencias da PETROBRAS, 15, 183-205, 2007.

Mohriak, W., Nemcok, M., and Enciso, G.: South Atlantic divergent margin evolution; rift-border uplift and salt tectonics in the basins of SE Brazil, in: Gondwana: Pre-Cenozoic Correlations Across the South Atlantic Region, Pankhurst, R. J., Trouw, R. A. J., Brito Neves, B. B., and De Wit, M. J., West Geological Society, London, Special Publications, 294, 365-398, 2008.

Mohriak, W. U. and Rosendahl, B. R.: Transform zones in the South Atlantic rifted continental margins, in: Intraplate strikeslip deformation belts, edited by: Storti, F., Holdsworth, R. E., and Salvini, F., Geological Society, London, Special Publication, 210, 211-228, 2003.

Mohriak, W. U., Lira Rabelo, J., De Matos, R. D., and De Barros, M. C.: Deep seismic reflection profiling of sedimentary basins offshore Brazil: Geological objectives and preliminary results in the Sergipe Basin, J. Geodynam., 20, 515-539, 1995.

Moulin, M., Aslanian, D., Rabineau, M., Patriat, M., and Matias, L.: Kinematic keys of the Santos-Namibe basins, in: Conjugate Divergent Margins, edited by: Mohriak, W. U., Danforth, A., Post, P. J., Brown, D. E., Tari, G. C., Nemcok, M., and Sinha, S. T., Geological Society, London, Special Publications, 369, 2012.

Moulin, M., Aslanian, D., Olivet, J.-L., Contrucci, I., Matias, L., Geli, L., Klingelhoefer, F., Nouze, H., Rehault, J.-P., and Unternehr, P.: Geological constraints on the evolution of the Angolan margin based on reflection and refraction seismic data ( $\mathrm{Za}-$ iAngo Project), Geophys. J. Int., 162, 793-810, 2005.

Moulin, M., Aslanian, D., and Unternehr, P.: A new starting point for the South and Equatorial Atlantic Ocean, Earth Sci. Rev., 98, 1-37, 2010.

Mussard, J. M.: Les palynomorphes, indicateurs des variations du niveau marin relatif : analyses quantitatives dans l'Albien supérieur de la République du Congo, in: Géologie de l'Afrique et de l'Atlantique Sud, Compte Rendus des Colloques de géologie d'Angers, 16-24 juillet 1994, edited by: Jardiné, S., de Klasz, I., and Debenay, J.-P., Mémoires du Bulletin des Centres de Recherche et d'Exploration-Production d'Elf, 16, 57-66, 1996.

Nürnberg, D. and Müller, R. D.: The tectonic evolution of the South Atlantic from Late Jurassic to present, Tectonophysics, 191, 27$53,1991$. 
Otis, R. M. and Schneidermann, N.: A failed hydrocarbon system; Rawson Basins, Argentina, AAPG Memoir, 73, 417-427, 2000.

Paredes, J. M., Foix, N., Colombo Piñol, F., Nillni, A., Allard, J. O., and Marquillas, R. A.: Volcanic and climatic controls on fluvial style in a high-energy system: the Lower Cretaceous Matasiete Formation, Golfo San Jorge basin, Argentina, Sediment. Geol., 202, 96-123, 2007.

Paz, J. D. S., Rossetti, D. F., and Macambira, M. J. B.: An Upper Aptian saline pan/lake system from the Brazilian equatorial margin: integration of facies and isotopes, Sedimentology, 52, 1303-1321, 2005.

Poulsen, C. J., Barron, E. J., Arthur, M. A., and Peterson, W. H.: Response of the Mid-Cretaceous global oceanic circulation to tectonic and $\mathrm{CO}_{2}$ forcings, Paleoceanography, 16, 576-592, 2001.

Poulsen, C. J., Jacob, R. L., Pierrehumbert, R. T., and Huynh, T. T.: Testing paleogeographic controls on a Neoproterozoic snowball Earth, Geophys. Res. Lett., 29, 1515, doi:10.1029/2001GL014352, 2002.

Poulsen, C. J., Gendaszek, A. S., and Jacob, R. L.: Did the rifting of the Atlantic Ocean cause the Cretaceous thermal maximum?, Geology, 31, 115-118, 2003.

Price, G. D.: The evidence and implications of polar ice during the Mesozoic, Earth Sci. Rev., 48, 183-210, 1999.

Puceat, E., Lecuyer, C., Sheppard, S. M. F., Dromart, G., Reboulet, S., and Grandjean, P.: Thermal evolution of Cretaceous Tethyan marine waters inferred from oxygen isotope composition of fish tooth enamels, Paleoceanography, 18, 7-1-7-12, 2003.

Puceat, E., Lecuyer, C., Donnadieu, Y., Naveau, P., Cappetta, H., Ramstein, G., Huber, B. T., and Kriwet, J.: Fish tooth $\delta^{18} \mathrm{O}$ revising Late Cretaceous meridional upper ocean water temperature gradients, Geology, 35, 107-110, 2007.

Rabinowitz, P. D. and LaBrecque, J.: The Mesozoic South Atlantic Ocean and Evolution of Its Continental Margins, J. Geophys. Res., 84, 5973-6002, 1979.

Rangel, H. D., Flores de Oliveira, J. L., and Caixeta, J. M.: Bacia de Jequitinhonha, Boletim de Geociências da PETROBRAS, 15, 475-483, 2007.

Royer, D. L., Berner, R. A., Montanez, I. P., Tabor, N. J., and Beerling, D. J.: $\mathrm{CO}_{2}$ as a primary driver of Phanerozoic climate, GSA Today, 14, 4-10, 2004.
Scotese, C. R., Boucot, A. J., and McKerrow, W. S.: Gondwanan palaeogeography and palaeoclimatology, J. Afr. Earth Sci., 28, 99-114, 1999.

Sewall, J. O., van de Wal, R. S. W., van der Zwan, K., van Oosterhout, C., Dijkstra, H. A., and Scotese, C. R.: Climate model boundary conditions for four Cretaceous time slices, Clim. Past, 3, 647-657, doi:10.5194/cp-3-647-2007, 2007.

Spencer, R. J. and Hardie, L. A.: Control of seawater composition by mixing of river waters and mid-oean ridge hydrothermal brines, in: Fluid mineral Interactions: A Tribute to H. G. Eugster, 2, edited by: Spencer, R. J. and Chou, I. M., San Antonio, Geochem. Soc. Spec. Publ., 409-419, 1990.

Spicer, R. A., Rees, P. M., Chapman, J. L., Jarzembowski, E. A., and Cantrill, D.: Cretaceous phytogeography and climate signals, Philos. T. Roy. Soc. Lond. B, 341, 277-286, 1993.

Teisserenc, P. and Villemin, J.: Sedimentary basin of Gabon; geology and oil systems, AAPG Memoir, 48, 117-199, 1990.

Torsvik, T. H., Rousee, S., Labails, C., and Smethurst, M. A.: A new scheme for the opening of the South Atlantic Ocean and the dissection of an Aptian salt basin, Geophys. J. Int., 177, 13151333, 2009.

Uliana, M. A. and Legaretta, L.: Hydrocarbon habitat in a triassicto-Cretaceous sub-Andean setting: Neuquén basin, Argentina, J. Petrol. Geol., 16, 397-420, 1993.

Usiglio, J.: Analyse de l'eau de la Méditerranée sur les côtes de France, Ann. Chemie, 27, 172-191, 1849.

Wardlaw, N. C.: Unusual Marine Evaporites with Salts of Calcium and Magnesium Chloride in Cretaceous basins of Sergipe, Brazil, Econ. Geol. Bull. Soc. Econ. Geol., 67, 156-168, 1972.

Wardlaw, N. C. and Nicholls, G. D.: Cretaceous Evaporites of Brazil and West Africa and Their Bearing on the Theory of Continent Separation, International Geological Congress, 24, Montreal, 43-55, 1972.

Warren, J. K.: Evaporites; sediments, resources, and hydrocarbons, Springer, Berlin, Heidelberg, New York, 2006.

Winter, W. R., Jahnert, R. J., and Franca, A. B.: Bacia de Campos, Boletim de Geociências da PETROBRAS, 15, 511-529, 2007.

Zalan, P. V.: Bacia de Brangança-Viseu, São Luís e Ilha Nova, Boletim de Geociências da PETROBRAS, 15, 341-345, 2007. 